Article

\title{
Effect of Feijoa Sellowiana Acetonic Extract on Proliferation Inhibition and Apoptosis Induction in Human Gastric Cancer Cells
}

\author{
Sabino Russi ${ }^{1,+}+\mathbb{C}$, Viviana Maresca ${ }^{2,+} \oplus$, Pietro Zoppoli ${ }^{1}{ }^{\mathbb{D}}$, Michele Aieta ${ }^{1}$, Graziella Marino ${ }^{1}$, \\ Alessandro Sgambato ${ }^{1}$, Orazio Ignomirelli ${ }^{1}$, Mario Ciuffi ${ }^{1}$, Tiziana Notarangelo ${ }^{1}$, \\ Adriana Basile ${ }^{2, *}$, Geppino Falco ${ }^{2,3, * \mathbb{C}}$ and Simona Laurino ${ }^{1}$ (D) \\ 1 IRCCS CROB-Referral Cancer Center of Basilicata, 85028 Rionero in Vulture (PZ), Italy; \\ sabino.russi@crob.it (S.R.); pietro.zoppoli@crob.it (P.Z.); michele.aieta@crob.it (M.A.); \\ graziella.marino@crob.it (G.M.); alessandro.sgambato@crob.it (A.S.); orazio.ignomirelli@crob.it (O.I.); \\ mario.ciuffi@crob.it (M.C.); tiziana.notarangelo@crob.it (T.N.); simona.laurino@crob.it (S.L.) \\ 2 Department of Biology, University of Naples Federico II, 80138 Naples, Italy; viviana.maresca@unina.it \\ 3 Biogem-Istituto di Biologia e Genetica Molecolare, 83031 Ariano Irpino (AV), Italy \\ * Correspondence: adbasile@unina.it (A.B.); geppino.falco@unina.it (G.F.); \\ Tel.: +39-081-25-38508 (A.B.); +39-081-67-90-92 (G.F.) \\ + These authors contributed equally to this work.
}

Received: 7 October 2020; Accepted: 29 October 2020; Published: 2 November 2020

\begin{abstract}
Gastric cancer (GC) still represents a relevant health problem in the world for both incidence and mortality rates. Many studies underlined that natural products consumption could reduce GC risk, indicating flavonoids as responsible for the beneficial effects through the modulation of several biological processes, such as the inhibition of cancer antioxidant defense and induction of apoptosis. Since Feijoa sellowiana fruit is known to contain high amounts of flavonoids, among which is flavone, we evaluated the antiproliferative and proapoptotic effects of $F$. sellowiana acetonic extract on GC cell lines through MTS and Annexin-V FITC assays. Among three GC cell lines tested, SNU-1 results being sensitive to both the F. sellowiana acetonic extract and synthetic flavone, which was used as the reference treatment. Moreover, we evaluated their antioxidant effects, assessing the activity of the antioxidant enzymes supeoxide dismutase (SOD), catalase (CAT) and glutathione peroxidase (GPx) in polymorphonuclear cells. We found a significant increase of their activity after exposure to both F. sellowiana acetonic extract and flavone, supporting the idea that a diet that includes flavone-rich fruits could be of benefit for health. In addition to this antioxidant effect on normal cells, this study indicates, for the first time, an anticancer effect of $F$. sellowiana acetonic extract in GC cells.
\end{abstract}

Keywords: gastric cancer; feijoa sellowiana; antioxidant activity; anticancer activity

\section{Introduction}

Gastric cancer (GC) represents the fifth-most common cancer in the world, with a high mortality rate [1,2]. To date, gastrectomy, chemotherapy and radiation therapy represent the main therapies for treating GC [3], which success is limited by anticancer drug resistance [4]. A significant role in GC prevention and management is played by a natural diet [5,6]; indeed, many studies highlighted that GC risk was mitigated by the intake of natural products [7]. These evidences were supported by numerous epidemiological studies that evaluated the anticancer activity of natural dietary products, including fruits, soy, vegetables, cereals and several spices [8,9]. Natural products could exert healthy effects due to phytochemicals [10], such as flavonoids. Humans cannot synthesize flavonoids [11], so they must be integrated within the diet. Flavonoids constitute a class of polyphenols that can be 
divided into the following six subgroup: flavones, flavanones, flavanols, flavonols, isoflavones and anthocyanidins [12]. Accordingly, the cancer risk could be reduced by flavonoids consumption by modulating several biological process, as well as the inhibition of cancer antioxidant defense [13], induction of apoptosis [14] and constraining angiogenesis [15]. In addition, it has been observed that an antimicrobial effect of several flavonoids inhibited Helicobacter pylori growth [16,17]. Although the literature data support the idea that flavonoids consumption inversely correlates with digestive tract cancers, epidemiological evidence remains poor. In a recent meta-analysis, it was reported that a flavonoids-rich diet could reduce GC risk and highlighted a difference between European and American and Asian populations [18,19]. Geographical variability of food intake could explain this diversity. Moreover, it has been demonstrated that flavonoids exert different effects on GC according to their subclass intake and the histological type or localization of GC $[20,21]$. Recently, we reported the antioxidant, antibacterial and anticancer activity of Feijoa sellowiana acetonic extract, identifying flavones as the most active components [16,22,23]. Feijoa sellowiana (O. Berg) Myrtaceae, also known as Acca sellowiana, originates from the subtropical zone of South America, but it is well-acclimated in California, Florida and Italy and, in general, in mild climate areas. Fruits are edible berries whose nutritional and organoleptic properties are remarkable. F. sellowiana contains many bioactive compounds, such as terpenes, tannins, quinones, steroidal saponins and methyl- and ethyl-benzoate, responsible of the typical strong "Feijoa-like" taste, high amounts of bioflavonoids or vitamin P and (P)-active polyphenols [24]. Pharmacological activities were demonstrated for the acetonic extract and pure substances from F. sellowiana. Among them, interestingly, antibacterial and antifungal activities have been observed [16,25-27], hypothesizing, in a more recent paper, also the target [23]. Moreover, in the last years, it has been demonstrated as the pivotal role in bacterial multidrug resistance (MDR) modulation [28], as well as the antibacterial activity related to MDR bacterial strains [29]. Several researchers showed the antioxidant activity on the reactive oxygen species (ROS) production from human peripheral whole-blood phagocytes [24,26,30], from red blood cells [31] and from human intestinal epithelial cells models, demonstrating that the acetonic extract significantly increased lactase and sucrase-isomaltase activity, preventing lipid peroxidation [32]. As for the action mechanism, it has been demonstrated that the anti-inflammatory activity of acetonic extract from $F$. sellowiana fruit was due to the action in the nitric oxide (NO) pathway. In particular, it was hypothesized that the modulation of inducible nitric oxide synthase (iNOS) enzyme expression was through the attenuation of nuclear factor-KB (NF-KB) and/or mitogen-activated protein kinase (MAPK) activation [33]. F. sellowiana anticancer activity was observed in both solid and hematological cancer cells, reporting no toxicity on normal myeloid progenitors, emphasizing a tumor-selective activity [22]. This effect was also demonstrated in vitro on human intestinal epithelial cells showing cell proliferation inhibition but not cytotoxicity [32]. Since the research concerning the effect of $F$. sellowiana acetonic extract against GC is limited, we investigated the proliferation inhibition and apoptosis induction by F. sellowiana extract in this kind of cancer. Moreover, we evaluated its antioxidant effect, supporting the idea that including this fruit in a diet may lower GC risk or improve treatment.

\section{Materials and Methods}

\subsection{Plant Material and Purification of the Active Compound}

Feijoa sellowiana (O. Berg) (Myrtaceae) fruits were collected from the Botanical Gardens of Naples (Italy). The identification was done by Prof. Adriana Basile, Department of Biology, University Federico II of Naples. A voucher specimen (NAP 96-125) was deposited at the Herbarium Neapolitanum (NAP), Botanical Garden, University Federico II of Naples. The acetonic extraction of F. sellowiana fruits was performed as previously described by Basile et al., 2010 [16]. 


\subsection{Blood Collection and Polymorphonuclear Leukocytes (PMN) Isolation}

Between 08.00 and 09.00 a.m., three healthy fasting donors were subjected to peripheral blood sampling with $\mathrm{K}_{3}$ EDTA vacutainers (Becton Dickinson, Plymouth, UK). A discontinuous gradient, consisting of $100 \%$ (density $1.1294 \mathrm{~g} / \mathrm{mL}$ ) and $70 \%$ (density $1.090 \mathrm{~g} / \mathrm{mL}$ ) isotonic Percoll (Pharmacia, Uppsala, Sweden) in calcium and magnesium-free phosphate-buffered saline, pH 7.4 (PBS; Sigma-Aldrich, Saint Louis, MO, USA), was used to isolate PMNs [34]. Subsequently, the samples were centrifuged for $20 \mathrm{~min}$ at $250 \times \mathrm{g}$ at room temperature. The PMN layer was collected and washed twice in PBS. May Grunwald Giemsa-stained cytocentrifuged smears were used to determine purity of the isolated PMNs, while the trypan blue dye exclusion test was employed to check cell viability. Both ranged between $90 \%$ and $95 \%$.

\subsection{Antioxidant Enzymes Activity Measure in PMN Cells}

A commercial kit (BioAssay System, San Diego, CA, USA) was used to determine the superoxide dismutase (SOD), catalase (CAT) and glutathione peroxidase (GPx) enzymatic activity in PMN cells. The activity of enzymes was expressed as U/L [35]. Acetonic extract was tested at the concentration of $567.7 \mu \mathrm{g} / \mathrm{mL}$, and synthetic flavone (F2003; Sigma-Aldrich) was tested at the concentration of $21.6 \mu \mathrm{g} / \mathrm{mL}$, which is the effective dose $50\left(\mathrm{ED}_{50}\right)$ value (apoptosis rate of SNU-1 cells) reported in Table 1.

\subsection{Cell Culture and Reagents}

The human GC cell lines AGS (ATCC ${ }^{\circledR}$ CRL-1739 ${ }^{\mathrm{TM}}$ ), SNU-1 (ATCC ${ }^{\circledR}$ CRL-5971) and KATOIII (ATCC ${ }^{\circledR}$ HTB-103) were obtained from ATCC (Manassas, VA, USA) and routinely cultured. In particular, AGS cells were cultured in Dulbecco's modified Eagle's medium (DMEM, GIBCO, Grand Island, NY, USA) supplemented with 10\% fetal bovine serum (FBS; GIBCO, Grand Island, NY, USA), 1\% l-glutamine and 1\% ampicillin/streptomycin. SNU-1 were maintained in RPMI 1640 supplemented with $10 \%$ FBS and 1\% ampicillin/streptomycin. KATOIII cells were grown in Iscove's modified Dulbecco's medium (IMDM; GIBCO, Grand Island, NY, USA) with 20\% FBS (GIBCO, Grand Island, NY, USA), $1 \%$ l-glutamine and $1 \%$ ampicillin/streptomycin. A humidified atmosphere at $37^{\circ} \mathrm{C}$ containing $5 \% \mathrm{CO}_{2}$ was used as the optimal culture condition. Flavone was dissolved in dimethyl sulfoxide (DMSO) at the stock concentration of $10,000 \mu \mathrm{g} / \mathrm{mL}$. F. sellowiana acetonic extract was resuspended in DMEM to obtain a stock solution of $10,000 \mu \mathrm{g} / \mathrm{mL}$.

\subsection{Cell Proliferation Assays}

Cell proliferation was estimated using an MTS assay. About 5000 cells (AGS and KATOIII) and 10,000 cells (SNU-1) were seeded in 200- $\mu$ l medium per well in a 96-well plate. Cells were incubated for $24 \mathrm{~h}$ and subsequently treated with increasing concentrations of flavone $(0,5,50$ and $100 \mu \mathrm{g} / \mathrm{mL})$ or F. sellowiana acetonic extract $(0,5,50$ and $500 \mu \mathrm{g} / \mathrm{mL})$. After 24 and $48 \mathrm{~h}$ of treatment, $20 \mu \mathrm{L}$ of the CellTiter 96 AQueous One Solution Reagent (Promega Corp., Madison, WI, USA) was added into each well, and cells were incubated at $37^{\circ} \mathrm{C}$ for $1.5 \mathrm{~h}$. Following incubation, absorbance was read at $490 \mathrm{~nm}$ using a VICTOR Nivo Multimode plate reader (PerkinElmer, Inc., Waltham, MA, USA).

\subsection{Cell Apoptosis Analysis}

Cells were seeded in 6-well plates and cultured to $70 \%$ confluence. The cells were subsequently treated with flavone or F. sellowiana acetonic extract using the same concentration and time points of the MTS assay. Cells were harvested, washed twice in cold PBS, centrifuged at $1500 \mathrm{rpm}$ and then resuspended in $1 \mathrm{X}$ binding buffer. Cells were double-stained using FITC Annexin-V Apoptosis Detection Kit I (BD Biosciences, Franklin Lakes, NJ, USA) according to the manufacturer's instructions. Cells were incubated for $15 \mathrm{~min}$ at room temperature in the dark, and apoptosis was detected using 
a Navios flow cytometer (Beckman Coulter, Miami, FL, USA). The data analysis was performed by Kaluza analysis software v2.1.

\subsection{Statistical Analysis}

Absorbance data from the MTS assay were converted as the percent of viability of untreated controls. Counts from the flow cytometry evaluation of apoptosis were reported as a percent fold increase as compared with the untreated controls. Data were reported as mean \pm SE. Differences between treatments and control groups were estimated by one sample $t$-test. Effective dose $50\left(\mathrm{ED}_{50}\right)$ was calculated by fitting data with a log-logistic model using the drc $\mathrm{R}$ package [36]. $P$-values $<0.05$ were considered significant. Analyses were performed using R software.

\section{Results}

\subsection{Antioxidant Enzymes Activity Measured in PMN Cells}

To evaluate the possible use of F. sellowiana fruits as nutraceutical, functional food or, perhaps, even in the pharmacological field, we assessed its antioxidant activity on PMNs, which can be considered, albeit with obvious precautions and caution, a model of normal cell response to the treatment. Therefore, the antioxidative enzymes status was measured by SOD, CAT and GPx activities in PMN cells treated with F. sellowiana acetonic extract and flavone. The activity of antioxidant enzymes in PMN cells rises after exposure to both the F. sellowiana extract and flavone, as compared to the control (samples not treated) (Figure 1). In particular, the activity of SOD, CAT and GPX enzymes was greater in PMN cells treated with flavone compared to the F. sellowiana acetonic extracts.

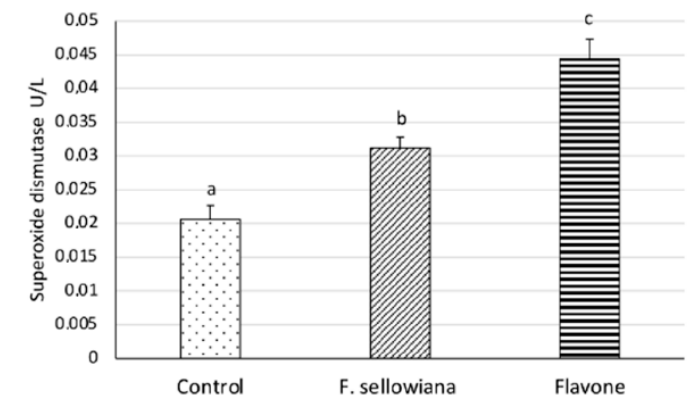

(a)

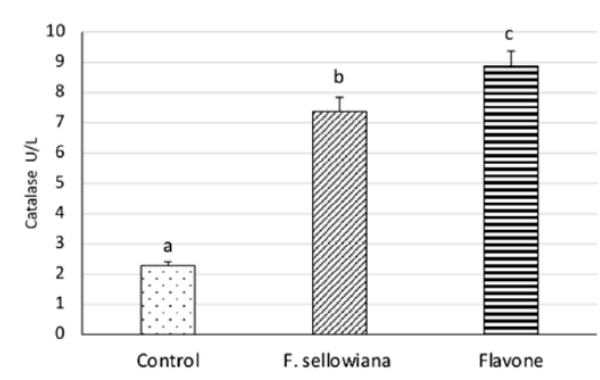

(b)

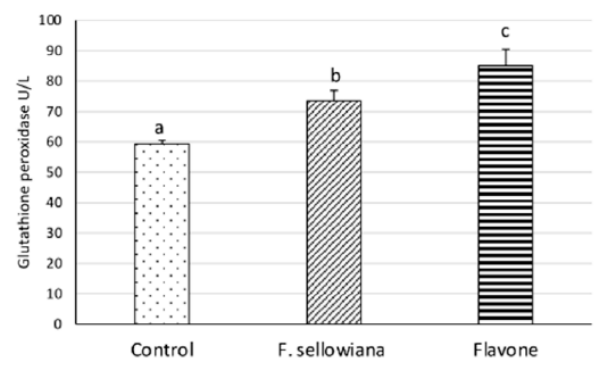

(c)

Figure 1. Effect of Feijoa sellowiana acetonic extract and flavone on the activity of antioxidant enzymes in polymorphonuclear cells. (a) Superoxide dismutase, (b) catalase and (c) glutathione peroxidase. Data were presented as mean and standard error and were analyzed with a paired $t$-test. Bars not accompanied by the same letter were significantly different at $p<0.05$.

\subsection{Cell Proliferation Assays}

Subsequently, we evaluated the effects of F. sellowiana acetonic extract on the GC cell line growth (AGS, KATOIII and SNU-1). In particular, cells were treated with three different concentrations of F. sellowiana acetonic extract $(5,50$ and $500 \mu \mathrm{g} / \mathrm{mL})$ or flavone $(5,50$ and $100 \mu \mathrm{g} / \mathrm{mL})$ for 24 and $48 \mathrm{~h}$. 
Flavone treatment was used as a reference to evaluate the efficacy and potency of the acetonic extract. The effect on cell proliferation was assessed by MTS assay. As shown in Figure 2, the F. sellowiana acetonic extract induced a significant decrease in SNU-1 cell proliferation in a dose- and time-dependent manner, with a maximum effect at $500 \mu \mathrm{g} / \mathrm{mL}$ and after $48 \mathrm{~h}$ of treatment, whereas no growth inhibitory effects were observed in AGS and KATOIII cells. The flavone effect was significant as early as after $24 \mathrm{~h}$ and at lower doses (50-100 $\mu \mathrm{g} / \mathrm{mL})$ as compared to the F. sellowiana acetonic extract. Furthermore, flavone seems to be more effective also to inhibit AGS and KATOIII cell proliferation.

(a)

(b)
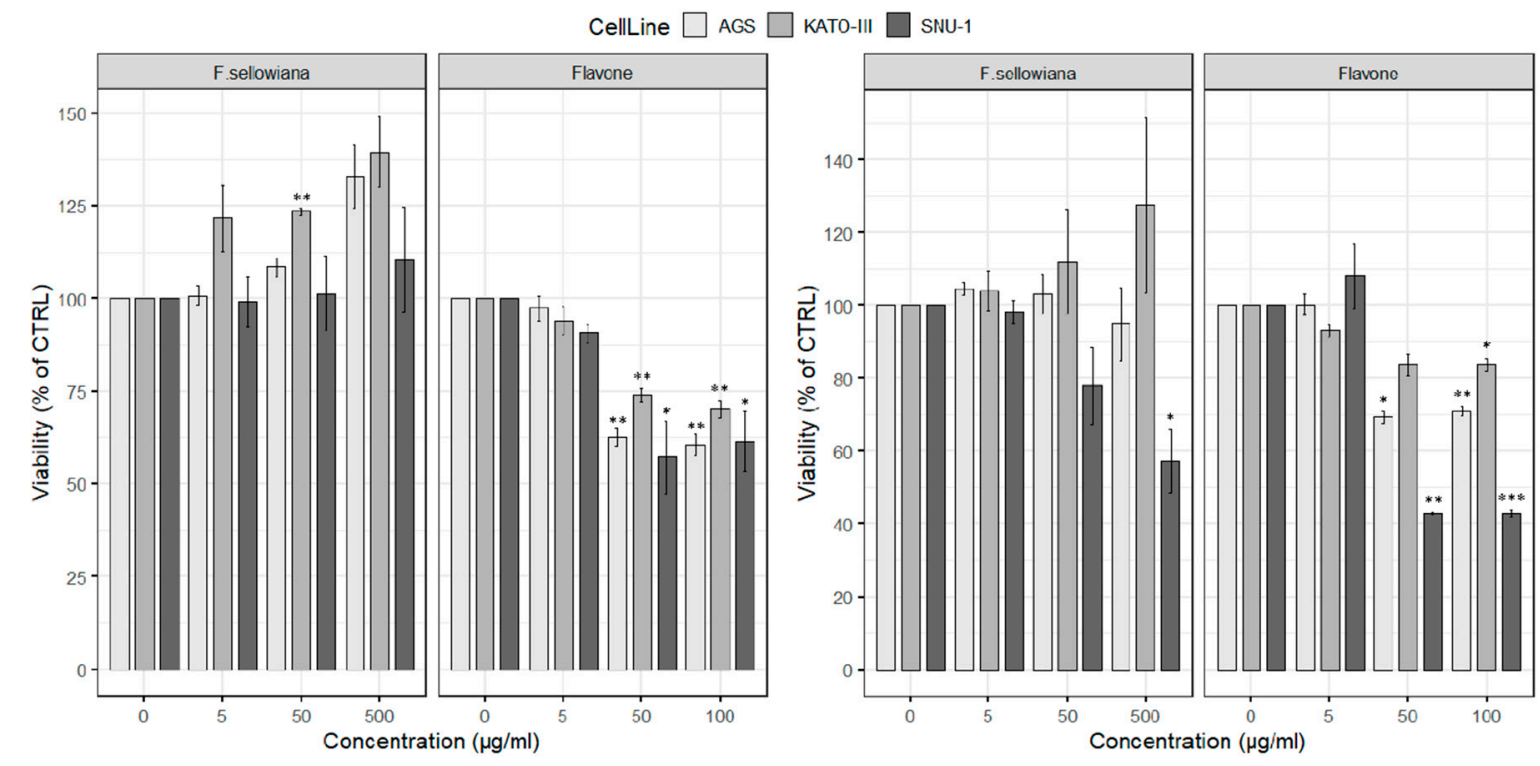

Figure 2. Effects of three different concentrations of F. sellowiana acetonic extract or flavone on cell proliferation. AGS, KATOIII and SNU-1 cells were treated for $24 \mathrm{~h} \mathrm{(a)} \mathrm{and} \mathrm{for} 48 \mathrm{~h}$ (b). MTS assay was used to determine cell proliferation. Data were expressed as \% of the number of viable, metabolically active cells compared to the control. Data were presented as mean and standard error of three individual experiments and analyzed with one sample $t$-test. ${ }^{*} p<0.05$, ${ }^{* *} p<0.001$ and ${ }^{* * *} p<0.0001$.

\subsection{Cell Apoptosis Analysis}

Based on the MTS results, we investigated whether apoptotic mechanisms were involved in the observed loss of proliferation in SNU-1 cells. As demonstrated in Figure 3, $500 \mu \mathrm{g} / \mathrm{mL}$ of F. sellowiana acetonic extract caused a significant decrease in the live cell rate, as well as a statistically significant increase of apoptotic cells both at 24 and $48 \mathrm{~h}$ compared to the untreated control. F. sellowiana acetonic extract induced apoptosis only at the highest concentration; it also induced necrosis in a similar manner at higher percentages.

Finally, comparing the effects of different doses of flavone, we confirmed the MTS data showing that flavone treatment resulted in a significant increase of apoptosis in the SNU-1 gastric cancer cell line in a time- and dose-dependent manner (Figure 4). In particular, after $48 \mathrm{~h}$ of treatment, flavone was shown to be effective to reduce the percentage of live cells at lower doses compared to $24 \mathrm{~h}$ exposure. Conversely, the duration of the treatment with F. sellowiana acetonic extract did not influence the apoptotic effect. 

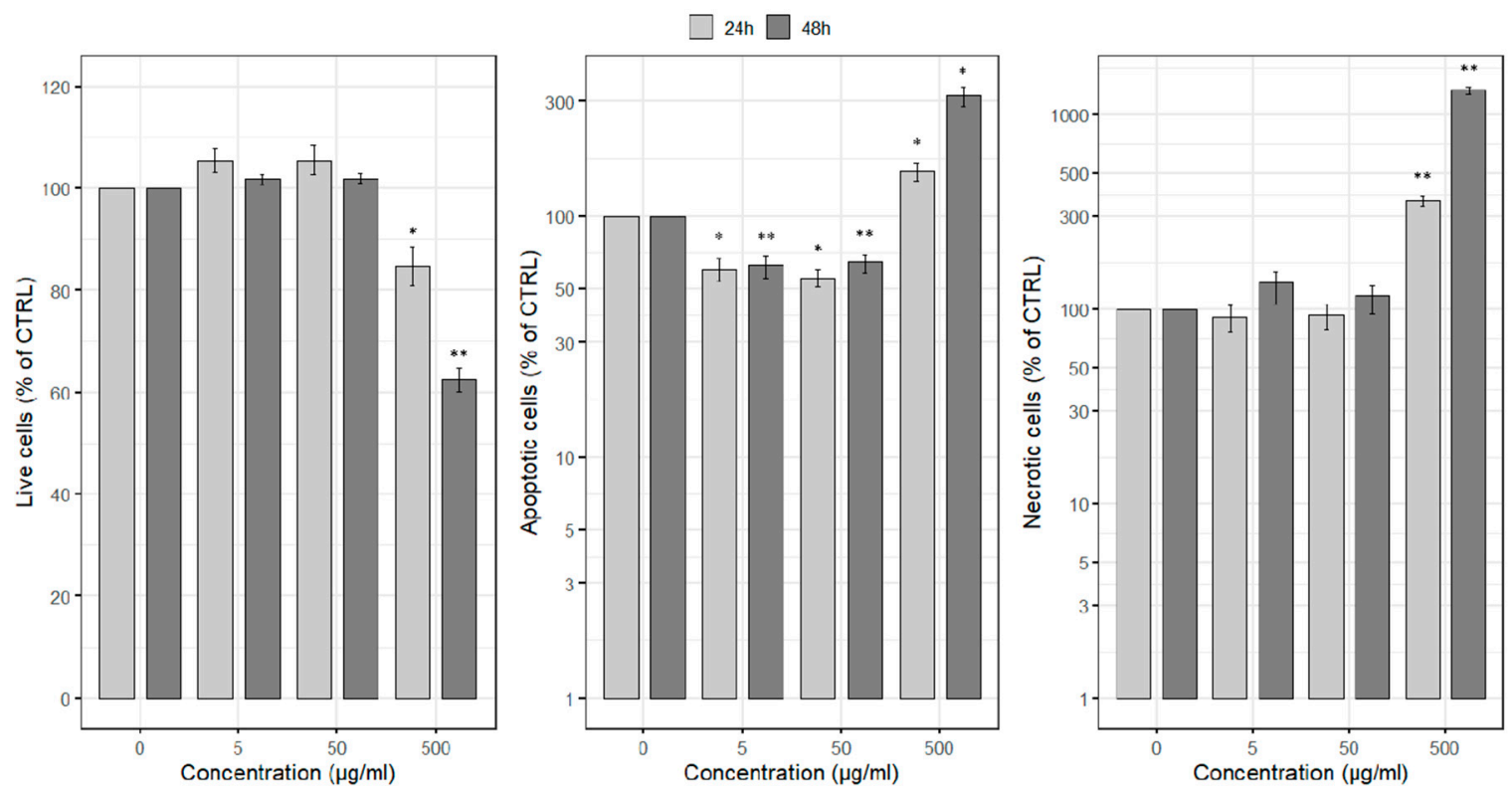

Figure 3. F. sellowiana acetonic extract induced apoptosis on SNU-1 cells. Cells $\left(2.5 \times 10^{5}\right)$ were treated with increasing concentrations of F. sellowiana extract for 24 and $48 \mathrm{~h}$. The amount of apoptotic cells was determined by flow cytometry. The apoptosis rate was estimated in comparison to the untreated cell. Data were presented as mean and standard error of three individual experiments and were analyzed with a one-sample $t$-test. ${ }^{*} p<0.05$ and ${ }^{* *} p<0.001$.
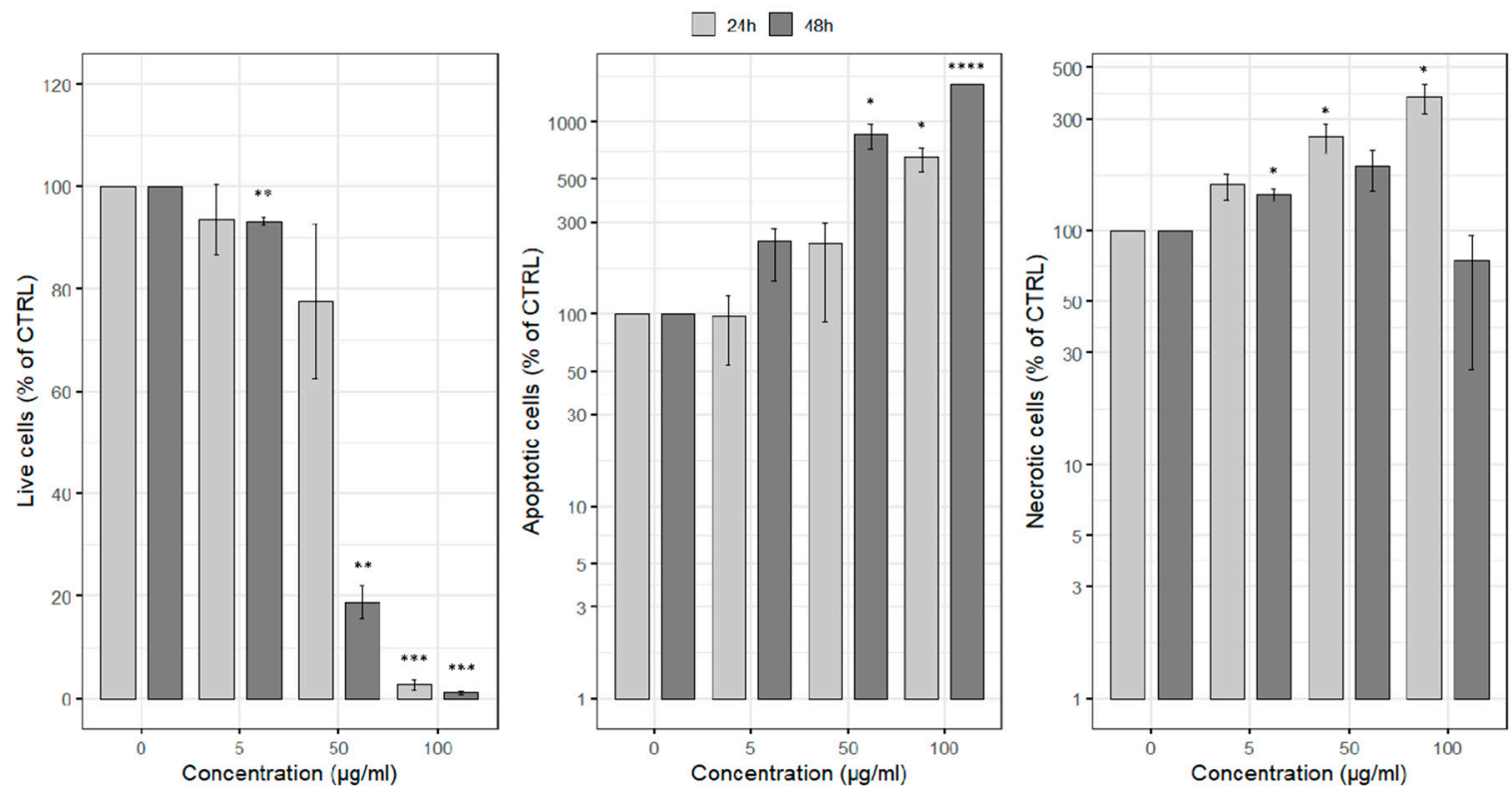

Figure 4. Flavone induces apoptosis in SNU-1 cells. Cells $\left(2.5 \times 10^{5}\right)$ were treated with increasing concentrations of flavone for $24 \mathrm{~h}$ and $48 \mathrm{~h}$, and the amount of apoptotic cells was determined by flow cytometry. The apoptosis rate was estimated in comparison to the untreated cell. Data were presented as mean and standard error of three individual experiments and were analyzed with a one-sample $t$-test. ${ }^{*} p<0.05,{ }^{* *} p<0.001,{ }^{* * *} p<0.0001$ and ${ }^{* * *} p<0.00001$.

Although both compounds increased the apoptosis rate, SNU-1 cells resulted in being more sensitive to flavone than the F. sellowiana acetonic extract, as evident from the $\mathrm{ED}_{50}$ values reported in Table 1. 
Table 1. Effective dose $50\left(\mathrm{ED}_{50}\right)$ values of the Feijoa sellowiana extract and flavone in SNU-1 cells.

\begin{tabular}{ccc}
\hline & ED $_{\mathbf{5 0}}$ Values & $(\mu \mathrm{g} / \mathbf{m L})$ \\
$\mathbf{2 4} \mathbf{~ h}$ & $\mathbf{4 8 ~ \mathbf { ~ }}$ \\
\hline $\begin{array}{c}\text { F. sellowiana } \\
\text { Extract }\end{array}$ & 1031.6 & 567.7 \\
$(p=0.67)$ & $(p<0.0001)$ \\
\hline Flavone & 59.7 & 21.6 \\
& $(p<0.0001)$ & $(p<0.0001)$ \\
\hline
\end{tabular}

\section{Discussion}

It is well-known that plant extracts bear bioactivities that, due to their high selectivity and, often, their capacity to be biodegradable in nontoxic products, can be applied similarly to other usual chemical drugs [37,38]. In particular, several studies described the important biological properties of extracts from the F. sellowiana fruit, including a strong antimicrobial (also against $H$. pylori) and antioxidant activity $[16,25,26]$ and significant nephro- and hepatoprotective, anti-inflammatory and antidepressant effects [39-41], as well as relevant anticancer activity [22,42,43]. In a previous study, Leuzzi et al. demonstrated a protective effect of F. sellowiana fruit extract on gastric mucosa [44]. Furthermore, several studies remarked that the main biological activities of F. sellowiana extract, such as antitumor, antimicrobial and anti-inflammatory effects, could be ascribable to several compounds. Among them, it is widely believed that flavone plays a very important role [16,22,33].

Indeed, epidemiological studies associated flavonoid ingestion to a lower risk of different types of cancer, including GC [45]; nonetheless, there is a risk of chronic disease [46]. Moreover, flavonoids seem to have no adverse effects, even at high dosages, and they are not chemically degraded by human stomach milieu [47]. Therefore, in the last years, the capacity of flavonoids to inhibit cell proliferation and/or induce apoptosis in human cancer cells has driven many researchers to investigate their potential as anticancer drugs. Increasing data revealed that one of the most active flavonoids was found to be flavone [22,48].

Based on these evidences, and considering the possible, still little-known, role played by $F$. sellowiana acetonic extract in the gastrointestinal tract, we investigated its anticancer effects, as well as its antioxidant activity, comparing them with those determined by the well-known flavone.

In this study, we demonstrated that, among three different gastric cancer cell lines, the F. sellowiana acetonic extract displayed antiproliferative effects and a concomitant apoptosis induction on SNU-1 cells. On the contrary, AGS and KATOIII cancer cells were poorly responsive to this treatment, according to previous studies that emphasized a cell line-specific sensitivity to F. sellowiana extract [22].

These evidences were supported also by some different characteristics between the cell lines used for the experiments. Indeed, since SNU-1 are ERBB2-positive cells, we can speculate that the apoptotic effects induced by the F. sellowiana acetonic extract could be similar to those induced by other flavonoids in other ERBB2+ tumor cell lines [49,50].

In agreement with the well-established anticancer activity of flavone and structurally related flavones in other types of cancer [51-53], we found that flavone was also able to induce apoptosis in all the three gastric cancer cell lines we used, reaching the maximal activity at $100 \mu \mathrm{g} / \mathrm{mL}$. Moreover, the different behavior of the gastric cancer cell lines could reflect, once again, the strong gastric cancer heterogeneity.

Our study supplied novel insights into the anticancer activities of the F. sellowiana acetonic extract related to gastric cancer.

Regarding the antioxidant properties, the choice to use PMNs to evaluate the effect of the extract on the activity of antioxidant enzymes is due to the fact that these cells represented a study model to evaluate the antioxidant response in previous studies on F. sellowiana extracts [26].

As for the anticancer effect, our results show that the antioxidant activity of SOD, CAT and GPX enzymes are higher in PMN cells treated with flavone compared to the F. sellowiana acetonic extracts. We can hypothesize that the greater activity of it could be ascribable to a lesser amount 
of pure flavone or to different molecules present in the extract that reduced the bioavailability of flavone. Alternatively, it can be due to the presence of other substances in the acetonic extract of $F$. sellowiana capable of negatively influencing the activity of antioxidant enzymes; or, simply, as already hypothesized about the antitumor activity, in the acetone extract, there may be substances capable of causing cellular suffering.

Our data, which showed an action on the activity of some antioxidant enzymes, provided a further step in the construction of the framework on the bioactivity of $F$. sellowiana. In fact, in addition to the inflammation reduction mediated by iNOS downregulation [33] and the direct antioxidant activity mediated by disaccharidases [32], the acetone extract and, even more, the flavone present in it could contribute to the antioxidant effect through an enzymatic-mediated way.

Recently, the development of novel functional foods or nutraceuticals has sped up stimulated by a strong awareness about the strict correlation between diet and health status/disease prevention favoring. Since F. sellowiana fruits contained several components with beneficial effects on health, such as dietary fibers, vitamins, antioxidants, minerals and iodine, as well as rich in bioflavonoids (vitamin P) $[24,54]$, it could be suitable to this purpose. Overall, the antitumor activity demonstrated on a vast panel of cell types and the results reported in the present work led us to advocate the possible application of $F$. sellowiana in the pharmaceutical, nutraceutical and/or functional food fields.

Author Contributions: Conceptualization, A.B., G.F. and S.L.; methodology, V.M., S.R. and T.N.; software, S.R. and P.Z.; validation, T.N. and V.M.; formal analysis, S.R. and P.Z.; investigation, A.B., G.F., V.M. and S.L.; resources, M.A., G.M., A.S., O.I. and M.C.; data curation, S.R., G.M. and V.M.; writing-original draft preparation, V.M., S.L. and S.R.; funding acquisition, S.L.; writing-review and editing, A.B., G.F., S.L., S.R., M.A. and V.M. and supervision, A.B., G.F., A.S. and S.L. All authors have read and agreed to the published version of the manuscript.

Funding: This work was supported by current research funds from Italian Ministry of Health to IRCCS-CROB, Rionero in Vulture, Potenza, Italy.

Conflicts of Interest: The authors declare no conflict of interest

\section{References}

1. Siegel, R.L.; Miller, K.D.; Jemal, A. Cancer statistics, 2019. CA Cancer J. Clin. 2019, 69, 7-34. [CrossRef] [PubMed]

2. Torre, L.A.; Siegel, R.L.; Ward, E.M.; Jemal, A. Global Cancer Incidence and Mortality Rates and Trends-An Update. Cancer Epidemiol. Biomarkers Prev. 2016, 25, 16-27. [CrossRef] [PubMed]

3. De Manzoni, G.; Marrelli, D.; Baiocchi, G.L.; Morgagni, P.; Saragoni, L.; Degiuli, M.; Donini, A.; Fumagalli, U.; Mazzei, M.A.; Pacelli, F.; et al. The Italian Research Group for Gastric Cancer (GIRCG) guidelines for gastric cancer staging and treatment: 2015. Gastric Cancer 2017, 20, 20-30. [CrossRef] [PubMed]

4. Mansoori, B.; Mohammadi, A.; Davudian, S.; Shirjang, S.; Baradaran, B. The different mechanisms of cancer drug resistance: A brief review. Adv. Pharm Bull. 2017, 7, 339-348. [CrossRef] [PubMed]

5. Ngoan, L.T.; Mizoue, T.; Fujino, Y.; Tokui, N.; Yoshimura, T. Dietary factors and stomach cancer mortality. Br. J. Cancer 2002, 87, 37-42. [CrossRef] [PubMed]

6. Turati, F.; Rossi, M.; Pelucchi, C.; Levi, F.; La Vecchia, C. Fruit and vegetables and cancer risk: A review of southern European studies. Br. J. Nutr. 2015, 113 (Suppl. S2), S102-S110. [CrossRef]

7. Fang, X.; Wei, J.; He, X.; An, P.; Wang, H.; Jiang, L.; Shao, D.; Liang, H.; Li, Y.; Wang, F.; et al. Landscape of dietary factors associated with risk of gastric cancer: A systematic review and dose-response meta-analysis of prospective cohort studies. Eur. J. Cancer 2015, 51, 2820-2832. [CrossRef]

8. Nouraie, M.; Pietinen, P.; Kamangar, F.; Dawsey, S.M.; Abnet, C.C.; Albanes, D.; Virtamo, J.; Taylor, P.R. Fruits, vegetables, and antioxidants and risk of gastric cancer among male smokers. Cancer Epidemiol. Biomark. Prev. 2005, 14, 2087-2092. [CrossRef]

9. Zhou, Y.; Li, Y.; Zhou, T.; Zheng, J.; Li, S.; Li, H.-B. Dietary natural products for prevention and treatment of liver cancer. Nutrients 2016, 8, 156. [CrossRef]

10. Mao, Q.-Q.; Xu, X.-Y.; Shang, A.; Gan, R.-Y.; Wu, D.-T.; Atanasov, A.G.; Li, H.-B. Phytochemicals for the prevention and treatment of gastric cancer: Effects and mechanisms. Int. J. Mol. Sci. 2020, 21, 570. [CrossRef] 
11. Kumar, S.; Pandey, A.K. Chemistry and biological activities of flavonoids: An overview. Sci. World J. 2013, 2013, 162750. [CrossRef]

12. Panche, A.N.; Diwan, A.D.; Chandra, S.R. Flavonoids: An overview. J. Nutr. Sci. 2016, 5, e47. [CrossRef] [PubMed]

13. Sznarkowska, A.; Kostecka, A.; Meller, K.; Bielawski, K.P. Inhibition of cancer antioxidant defense by natural compounds. Oncotarget 2017, 8, 15996-16016. [CrossRef]

14. Ramos, S. Effects of dietary flavonoids on apoptotic pathways related to cancer chemoprevention. J. Nutr. Biochem. 2007, 18, 427-442. [CrossRef] [PubMed]

15. Khalid, E.B.; Ayman, E.-M.E.-K.; Rahman, H.; Abdelkarim, G.; Najda, A. Natural products against cancer angiogenesis. Tumour Biol. 2016, 37, 14513-14536. [CrossRef]

16. Basile, A.; Conte, B.; Rigano, D.; Senatore, F.; Sorbo, S. Antibacterial and antifungal properties of acetonic extract of Feijoa sellowiana fruits and its effect on Helicobacter pylori growth. J. Med. Food 2010, 13, 189-195. [CrossRef]

17. Baltas, N.; Karaoglu, S.A.; Tarakci, C.; Kolayli, S. Effect of propolis in gastric disorders: Inhibition studies on the growth of Helicobacter pylori and production of its urease. J. Enzyme Inhib. Med. Chem. 2016, 31, 46-50. [CrossRef] [PubMed]

18. Bo, Y.; Sun, J.; Wang, M.; Ding, J.; Lu, Q.; Yuan, L. Dietary flavonoid intake and the risk of digestive tract cancers: A systematic review and meta-analysis. Sci. Rep. 2016, 6, 24836. [CrossRef]

19. Petrick, J.L.; Steck, S.E.; Bradshaw, P.T.; Trivers, K.F.; Abrahamson, P.E.; Engel, L.S.; He, K.; Chow, W.H.; Mayne, S.T.; Risch, H.A.; et al. Dietary intake of flavonoids and oesophageal and gastric cancer: Incidence and survival in the United States of America (USA). Br. J. Cancer 2015, 112, 1291-1300. [CrossRef]

20. Vitelli Storelli, F.; Molina, A.J.; Zamora-Ros, R.; Fernández-Villa, T.; Roussou, V.; Romaguera, D.; Aragonés, N.; Obón-Santacana, M.; Guevara, M.; Gómez-Acebo, I.; et al. Flavonoids and the Risk of Gastric Cancer: An Exploratory Case-Control Study in the MCC-Spain Study. Nutrients 2019, 11, 967. [CrossRef]

21. Lunet, N.; Valbuena, C.; Vieira, A.L.; Lopes, C.; Lopes, C.; David, L.; Carneiro, F.; Barros, H. Fruit and vegetable consumption and gastric cancer by location and histological type: Case-control and meta-analysis. Eur. J. Cancer Prev. 2007, 16, 312-327. [CrossRef]

22. Bontempo, P.; Mita, L.; Miceli, M.; Doto, A.; Nebbioso, A.; De Bellis, F.; Conte, M.; Minichiello, A.; Manzo, F.; Carafa, V.; et al. Feijoa sellowiana derived natural Flavone exerts anti-cancer action displaying HDAC inhibitory activities. Int. J. Biochem. Cell Biol. 2007, 39, 1902-1914. [CrossRef]

23. Di Napoli, M.; Maresca, V.; Sorbo, S.; Varcamonti, M.; Basile, A.; Zanfardino, A. Proteins of the fruit pulp of Acca sellowiana have antimicrobial activity directed against the bacterial membranes. Nat. Prod. Res. 2019, 1-5. [CrossRef]

24. Ielpo, M.T.L.; Basile, A.; Miranda, R.; Moscatiello, V.; Nappo, C.; Sorbo, S.; Laghi, E.; Ricciardi, M.M.; Ricciardi, L.; Vuotto, M.L. Immunopharmacological properties of flavonoids. Fitoterapia 2000, 71, S101-S109. [CrossRef]

25. Basile, A.; Vuotto, M.L.; Violante, U.; Sorbo, S.; Martone, G.; Castaldo-Cobianchi, R. Antibacterial activity in Actinidia chinensis, Feijoa sellowiana and Aberia caffra. Int. J. Antimicrob. Agents 1997, 8, 199-203. [CrossRef]

26. Vuotto, M.L.; Basile, A.; Moscatiello, V.; De Sole, P.; Castaldo-Cobianchi, R.; Laghi, E.; Ielpo, M.T. Antimicrobial and antioxidant activities of Feijoa sellowiana fruit. Int. J. Antimicrob. Agents 2000, 13, 197-201. [CrossRef]

27. Piscopo, M.; Tenore, G.C.; Notariale, R.; Maresca, V.; Maisto, M.; de Ruberto, F.; Heydari, M.; Sorbo, S.; Basile, A. Antimicrobial and antioxidant activity of proteins from Feijoa sellowiana Berg. fruit before and after in vitro gastrointestinal digestion. Nat. Prod. Res. 2020, 34, 2607-2611. [CrossRef]

28. Motohashi, N.; Kawase, M.; Shirataki, Y.; Tani, S.; Saito, S.; Sakagami, H.; Kurihara, T.; Nakashima, H.; Wolfard, K.; Mucsi, I.; et al. Biological activity of feijoa peel extracts. Anticancer Res. 2000, 20, 4323-4329.

29. Dell'Olmo, E.; Gaglione, R.; Pane, K.; Sorbo, S.; Basile, A.; Esposito, S.; Arciello, A. Fighting multidrug resistance with a fruit extract: Anti-cancer and anti-biofilm activities of Acca sellowiana. Nat. Prod. Res. 2019, 1-4. [CrossRef]

30. Basile, A.; Vuotto, M.L.; Ricciardi, L.; Pezone, L.; Mancino, D.; Senatore, F.; De Prisco, R. Antimicrobial and antioxidant activities in Feijoa sellowiana skin and pulp. In Bioluminescence and Chemiluminescence; World Scientific: Singapore, 2001; pp. 223-226. 
31. Tortora, F.; Notariale, R.; Maresca, V.; Good, K.V.; Sorbo, S.; Basile, A.; Piscopo, M.; Manna, C. Phenol-Rich Feijoa sellowiana (Pineapple Guava) Extracts Protect Human Red Blood Cells from Mercury-Induced Cellular Toxicity. Antioxidants 2019, 8, 220. [CrossRef]

32. Turco, F.; Palumbo, I.; Andreozzi, P.; Sarnelli, G.; De Ruberto, F.; Esposito, G.; Basile, A.; Cuomo, R. Acetonic Extract from the Feijoa sellowiana Berg. Fruit Exerts Antioxidant Properties and Modulates Disaccharidases Activities in Human Intestinal Epithelial Cells. Phytother Res. 2016, 30, 1308-1315. [CrossRef] [PubMed]

33. Rossi, A.; Rigano, D.; Pergola, C.; Formisano, C.; Basile, A.; Bramanti, P.; Senatore, F.; Sautebin, L. Inhibition of inducible nitric oxide synthase expression by an acetonic extract from Feijoa sellowiana Berg. fruits. J. Agric. Food Chem. 2007, 55, 5053-5061. [CrossRef]

34. Harbeck, R.J.; Hoffman, A.A.; Redecker, S.; Biundo, T.; Kurnick, J. The isolation and functional activity of polymorphonuclear leukocytes and lymphocytes separated from whole blood on a single percoll density gradient. Clin. Immunol. Immunopathol. 1982, 23, 682-690. [CrossRef]

35. Barbosa, P.O.; Pala, D.; Silva, C.T.; de Souza, M.O.; do Amaral, J.F.; Vieira, R.A.L.; Folly, G.A.; Volp, A.C.P.; de Freitas, R.N. Açai (Euterpe oleracea Mart.) pulp dietary intake improves cellular antioxidant enzymes and biomarkers of serum in healthy women. Nutrition 2016, 32, 674-680. [CrossRef]

36. Ritz, C.; Baty, F.; Streibig, J.C.; Gerhard, D. Dose-Response Analysis Using R. PLoS ONE 2015, 10 , e0146021. [CrossRef] [PubMed]

37. Ríos, J.L.; Recio, M.C. Medicinal plants and antimicrobial activity. J. Ethnopharmacol. 2005, 100, 80-84. [CrossRef]

38. Di Napoli, M.; Maresca, V.; Varcamonti, M.; Bruno, M.; Badalamenti, N.; Basile, A.; Zanfardino, A. (+)-(E)-Chrysanthenyl Acetate: A Molecule with Interesting Biological Properties Contained in the Anthemis secundiramea (Asteraceae) Flowers. Appl. Sci. 2020, 10, 6808. [CrossRef]

39. Karami, M.; Saeidnia, S.; Nosrati, A. Study of the Hepatoprotective Activity of Methanolic Extract of Feijoa sellowiana Fruits Against MDMA using the Isolated Rat Liver Perfusion System. Iran. J. Pharm Res. 2013, 12, 85-91.

40. Karami, M.; Karimian Nokabadi, F.; Ebrahimzadeh, M.A.; Naghshvar, F. Nephroprotective effects of Feijoa Sellowiana leaves extract on renal injury induced by acute dose of ecstasy (MDMA) in mice. Iran. J. Basic Med. Sci. 2014, 17, 69-72.

41. Mahmoudi, M.; Ebrahimzadeh, M.A.; Abdi, M.; Arimi, Y.; Fathi, H. Antidepressant activities of Feijoa sellowiana fruit. Eur. Rev. Med. Pharmacol. Sci 2015, 19, 2510-2513.

42. Kikuchi, H.; Yuan, B.; Hu, X.; Okazaki, M. Chemopreventive and anticancer activity of flavonoids and its possibility for clinical use by combining with conventional chemotherapeutic agents. Am. J. Cancer Res. 2019, 9, 1517-1535.

43. Abe, I.; Seki, T.; Umehara, K.; Miyase, T.; Noguchi, H.; Sakakibara, J.; Ono, T. Green tea polyphenols: Novel and potent inhibitors of squalene epoxidase. Biochem. Biophys. Res. Commun. 2000, 268, 767-771. [CrossRef]

44. Leuzzi, A.; Galati, E.M.; Mondello, M.R.; Monforte, M.T. Antiulcer activity of Feijoa sellowiana L. (Mirtaceae): Morphological study. Planta Med. 2009, 75. [CrossRef]

45. Yoshimizu, N.; Otani, Y.; Saikawa, Y.; Kubota, T.; Yoshida, M.; Furukawa, T.; Kumai, K.; Kameyama, K.; Fujii, M.; Yano, M.; et al. Anti-tumour effects of nobiletin, a citrus flavonoid, on gastric cancer include: Antiproliferative effects, induction of apoptosis and cell cycle deregulation. Aliment. Pharmacol. Ther. 2004, 20 (Suppl. S1), 95-101. [CrossRef]

46. Knekt, P.; Kumpulainen, J.; Järvinen, R.; Rissanen, H.; Heliövaara, M.; Reunanen, A.; Hakulinen, T.; Aromaa, A. Flavonoid intake and risk of chronic diseases. Am. J. Clin. Nutr. 2002, 76, 560-568. [CrossRef]

47. Tombola, F.; Campello, S.; De Luca, L.; Ruggiero, P.; Del Giudice, G.; Papini, E.; Zoratti, M. Plant polyphenols inhibit VacA, a toxin secreted by the gastric pathogen Helicobacter pylori. FEBS Lett. 2003, 543, 184-189. [CrossRef]

48. Cushnie, T.P.T.; Lamb, A.J. Antimicrobial activity of flavonoids. Int. J. Antimicrob. Agents 2005, 26, 343-356. [CrossRef]

49. Chandrika, B.B.; Steephan, M.; Kumar, T.R.S.; Sabu, A.; Haridas, M. Hesperetin and Naringenin sensitize HER2 positive cancer cells to death by serving as HER2 Tyrosine Kinase inhibitors. Life Sci. 2016, 160, 47-56. [CrossRef] [PubMed] 
50. Samarghandian, S.; Azimi-Nezhad, M.; Borji, A.; Hasanzadeh, M.; Jabbari, F.; Farkhondeh, T.; Samini, M. Inhibitory and cytotoxic activities of chrysin on human breast adenocarcinoma cells by induction of apoptosis. Pharmacogn. Mag. 2016, 12, S436-S440.

51. Chen, Y.-C.; Shen, S.-C.; Chow, J.-M.; Ko, C.; Tseng, S.-W. Flavone inhibition of tumor growth via apoptosis in vitro and in vivo. Int. J. Oncol. 2004. [CrossRef]

52. Zhu, W.; Yang, B.; Fu, H.; Ma, L.; Liu, T.; Chai, R.; Zheng, Z.; Zhang, Q.; Li, G. Flavone inhibits nitric oxide synthase (NOS) activity, nitric oxide production and protein S-nitrosylation in breast cancer cells. Biochem. Biophys. Res. Commun. 2015, 458, 590-595. [CrossRef] [PubMed]

53. Kopustinskiene, D.M.; Jakstas, V.; Savickas, A.; Bernatoniene, J. Flavonoids as anticancer agents. Nutrients 2020, 12, 457. [CrossRef]

54. Romero Rodriguez, M.A.; Vazquez Oderiz, M.L.; Lopez Hernandez, J.; Lozano, J.S. Determination of vitamin $\mathrm{C}$ and organic acids in various fruits by HPLC. J. Chromatogr. Sci. 1992, 30, 433-437. [CrossRef] [PubMed]

Publisher's Note: MDPI stays neutral with regard to jurisdictional claims in published maps and institutional affiliations.

(C) 2020 by the authors. Licensee MDPI, Basel, Switzerland. This article is an open access article distributed under the terms and conditions of the Creative Commons Attribution (CC BY) license (http://creativecommons.org/licenses/by/4.0/). 